\title{
SCHUMPETER VS. KEYNES: “IN THE LONG RUN NOT ALL OF US ARE DEAD”,
}

\author{
BY \\ ARTHUR M. DIAMOND, JR.
}

\begin{abstract}
Keynes was viewed by himself, Schumpeter, and most others as the most highly esteemed economist of the twentieth century. However, Schumpeter is receiving increasing attention from mainstream economists. A few specific examples are discussed, and the citation time series for Keynes and Schumpeter are compared for the period 1956 through 2006. Generally, Keynes receives more citations than Schumpeter from 1956 through roughly the mid-1990s. But subsequently until 2006, Schumpeter received more citations than Keynes.
\end{abstract}

\section{INTRODUCTION}

Now, at the turn of the millennia, when total-factor-productivity has remarkably soared in America and abroad, both fools and sages sing Schumpeter's praise. That would have amused and pleased this worldly scholar who in some dark hours of the night used to despair in his German-shorthand diaries of justly deserved praises passing him by. So Keynes was wrong: in the long run not all of us are dead.

— Paul Samuelson 2003, p. $467 .^{1}$

John Maynard Keynes famously told us that "in the long run we are all dead." Karl Marx confirmed Keynes' hypothesis, by dying in 1883, the same year in which Keynes and Joseph Schumpeter were born. The coincidence of three such important events for the economics profession has not gone unnoticed, and served as the stimulus for at least two academic conferences. ${ }^{2}$ The economists share more than 1883. All three are important figures, with important alternative views on how capitalism works, whether it is good for the masses, and its prospects for the future. Schumpeter wrote extensively on Marx, arguing ironically that Marx was prescient in foreseeing the decline of capitalism, but also arguing, contra Marx, that capitalism

Department of Economics, University of Nebraska at Omaha, Omaha, NE 68182-0048. Phone: (402) 554-3657. Fax: (402) 554-2853. email: adiamond@unomaha.edu

${ }^{1}$ I also considered starting the paper with: "No one in the interwar years was more brilliant, more clever than Keynes. Schumpeter, by contrast, appeared pedestrian—but he had wisdom. Cleverness carries the day. But wisdom endureth." Peter Drucker (1999), p. 115.

${ }^{2}$ Two separate conferences were held in 1983, each resulting in the publication of its own conference volume: Helburn and Bramhall (1986) and Wagener and Drukker (1986). 
benefited the masses, rather than impoverishing them. Keynes could be viewed as a moderating figure, since he is sometimes seen as "saving" capitalism from Marx's predictions of demise, by using the government to cure capitalist downturns.

In a famous story about Schumpeter, he reflects that early in his life his ambition was to be the world's greatest horseman, economist, and lover; and that at the end of his life he had achieved two of the three. In Samuelson's version of the story, Schumpeter goes on to express regrets at his failings as a horseman (Samuelson 1981, p. 1). Was he the world's greatest economist?

Shortly after the deaths of Keynes and Schumpeter, the academic world and the world of policy makers would have given the title to Keynes. ${ }^{3}$ Keynes himself probably shared that view. In another famous story, a reporter asks Keynes to identify the world's greatest living economist, and Keynes is reputed to have answered that modesty did not permit him to answer, but that the world's second greatest living economist was Jacob Viner's draftsman.

Schumpeter himself, in his final years, privately acknowledged the greater recognition that Keynes had achieved, and viewed himself as having been a failure.

The main issue in the present paper is to measure the casual observations of Samuelson and others, primarily on the issue of the rise in the esteem for Schumpeter among academics, but secondarily on the issue of the relative esteem for Schumpeter and Keynes. Using citation data from the most extensive (and expensive) version of the Social Sciences Citation Index portion of the Web of Science, we have collected annual citations from 1956 through 2006 for Schumpeter and Keynes generally, and for Capitalism, Socialism and Democracy and The General Theory specifically.

The results show that until roughly the mid-1990s The General Theory was more influential, but that roughly since the mid-1990s Capitalism, Socialism and Democracy has become more influential.

\section{GROWING ACCEPTANCE AMONG ACADEMIC ECONOMISTS OF CREATIVE DESTRUCTION}

Some subgroups of academic economists have continued to value the contributions of Schumpeter in the 50 years since his passing. In particular, those who study the History of Economic Thought still value Schumpeter's History of Economic Analysis as a major source in field. The work serves both as a reference unrivaled in its comprehensiveness, and also as a continuing source of research questions. Similarly, those who study the Economics of Technology view Schumpeter as a founder of their field and as the source of several important research hypotheses. ${ }^{4}$

\footnotetext{
3“It is generally agreed among scholars that the public perception was that (by 1950) Keynes had scooped Schumpeter in popular attention as the world's most celebrated economist." Moss (1996), p. 10.

${ }^{4}$ Mansfield credits Schumpeter with founding the field (1995, I, p. ix). Rosenberg has gone so far as to say: " ... the study of technological innovation ... still consists of a series of footnotes upon Schumpeter." (Rosenberg 1982, p. 106) Griliches (2000, p. 45) lists Schumpeter with four other "major" early economists who recognized the importance of technological innovation. Granstrand notes that "J. Schumpeter is without doubt the father of the field in terms of citation appearance and influence upon others, as is widely acknowledged." (Granstrand, 1994, p. 19)
} 
But when I detect a growing acceptance of Schumpeter's central message, I am not primarily referring to either of these two groups. Rather I mainly intend a broader group - of otherwise more mainstream economists who believe that the broad features of Schumpeter's account of competition capture the kind of competition that is most important for understanding economic growth.

One economist often identified as solidly in the mainstream is Nobel-prize winner George Stigler. As in his note against Liebenstein, "The Xistence of X-efficiency," Stigler often defended the neo-classical, partial-equilibrium framework from heterodox criticism. His mid-career "Perfect Competition, Historically Contemplated" (1957) is devoted to an historical account of some of the main ways in which competition has been defined and discussed in economics through the mid-1950s. A secondary aim of this article is to argue for the usefulness and robustness of the competition concept, both in economic theory and as a policy tool. Stigler does, however, grant that the concept will need to continue to evolve with the advance of economic theory. In particular, he suggests (p. 282) that the concept of competition's "natural affinity to the static economy" will require modification in order to apply competition to a dynamic economy. This discussion calls Schumpeter to mind, but Stigler does not mention him.

Early in his career, Stigler advocated government antitrust action to make industry less concentrated and more competitive. Later, he became much less supportive of antitrust action. He claimed that the main reason for his change of position was the work of John McGee at the University of Chicago law school, under Aaron Director, demonstrating that the paradigm case of antitrust action- the Standard Oil case- - had been ill-founded in the sense that the greater efficiencies of the Standard Oil trust had benefited consumers.

But Stigler admitted that reading Schumpeter had provided a second reason for his change of position:

... Schumpeter painted an unconventional picture of the capitalistic process. The competition between the Pennsylvania and New York Central Railroads, he argued, might be sporadic and even trifling, but the competition to railroads provided by new transportation media such as trucks, automobiles, and airplanes really mattered... . We economists mostly rebelled against such heresy, but it left its mark (Stigler 1985, p. 101).

A mainstream economist who has acknowledged the importance of creative destruction in even stronger terms is William Baumol, who has been described by Joel Mokyr (2002) as "one of our most influential, original, and eminent economists for over half a century." In his essay on "Innovation and Creative Destruction," Baumol states (2001, p. 21) that the "clear message" of creative destruction "is that innovation and growth force obsolete technical configurations to be swept away without hesitation or remorse." He further acknowledges (2001, p. 21) that "Schumpeter surely does imply that without creative destruction we would be condemned to stagnation and forced to forgo the improvements of living standards offered by technical progress." His book The Free-Market Innovation Machine (2002) consists largely of a discussion and formal modeling of aspects of Schumpeter's process of creative destruction.

Several younger economists loosely in the "mainstream" have also recently argued for the importance of the process of creative destruction in understanding 


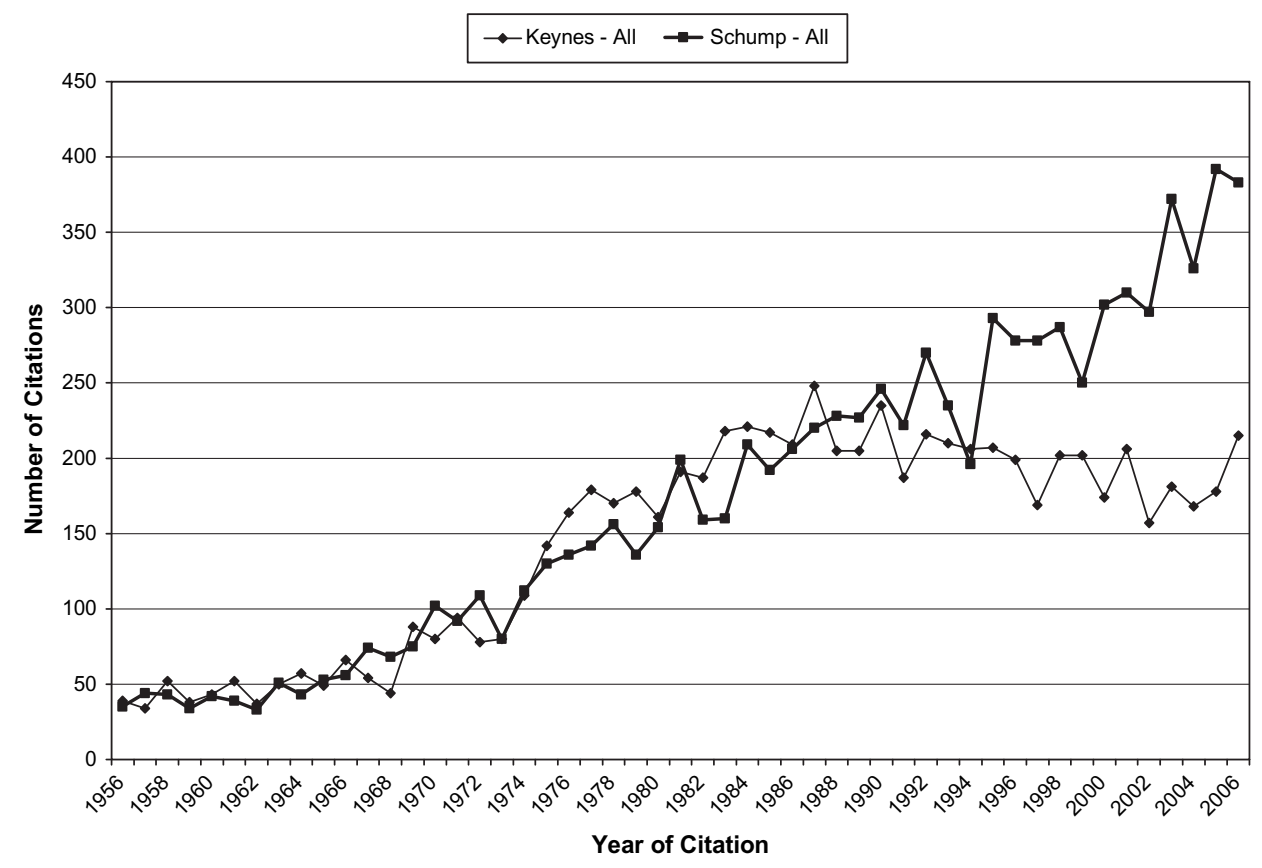

FIguRE 1. Schumpeter Versus Keynes: Total Citations Per Year to All Publications

economic growth and productivity. Among these economists are Bradford DeLong, Larry Summers, Martin Neil Baily, and Martin Feldstein.

\section{SOCIAL SCIENCE CITATIONS TO SCHUMPETER (AND KEYNES) FROM 1956 TO 2006}

Several important examples may establish a presumption, but a larger sample of academics would strengthen the case. To provide such a sample, I decided to use the Social Sciences Citation Index to examine the citations over time to Schumpeter and to Capitalism, Socialism and Democracy. ${ }^{5}$ The book versions of the data go back only through 1966, so I used the online Web of Science version, which has been extended back through 1956.

Because Schumpeter is so often compared to Keynes, I collected comparable citation data for John Maynard Keynes and for The General Theory of Employment,

\footnotetext{
${ }^{5}$ Earlier citation counts for Schumpeter have been made, over more limited time periods. For example, Samuelson says $(1981$, p. 1) that “..., at the time of his death, a citation index shows that Joseph Schumpeter was the scholar most often cited in the whole field of economics." Samuelson, unfortunately, provides no reference for this count, and I am not aware of its source. Dogan and Pahre (1990, p. 424) for the period "between 1981 and 1985 according to the SSCI" report 2,000 citations for Keynes and 1,600 citations for Schumpeter. (Although they do not explain their citation numbers, throughout their paper they seem to have rounded citation counts to the nearest hundred.)
} 


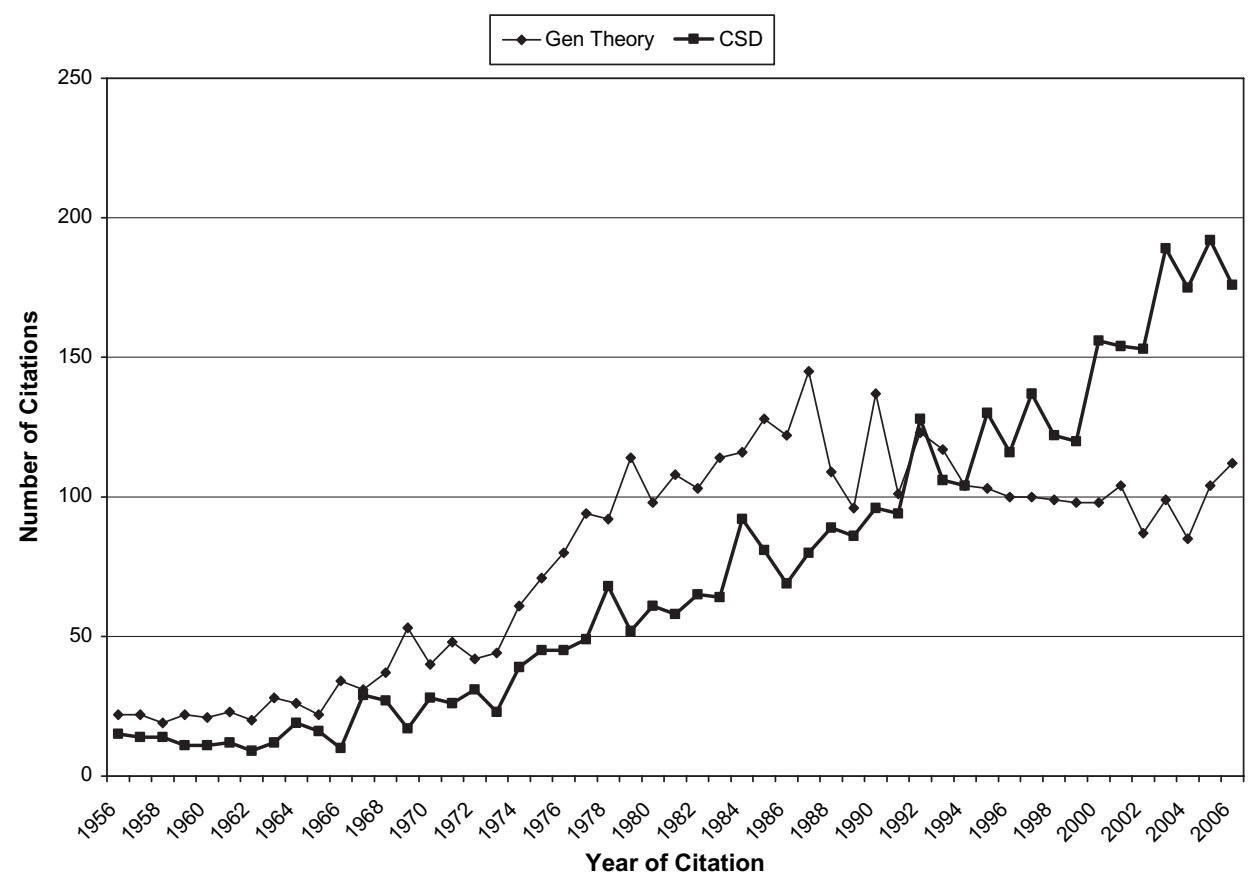

Figure 2. Schumpeter Versus Keynes: Citations Per Year to Capitalism, Socialism and Democracy Versus Citations Per Year to The General Theory

Interest, and Money. (Some of the details of the citation analysis are discussed in the Appendix on Citation Issues that is located after the tables and graphs near the end of this paper.)

Figure 1 reports total citations per year to Schumpeter and to Keynes. What is most important for our purposes is Schumpeter's continuing increase in annual citations, even more than 50 years after his death. As far as the Keynes/Schumpeter comparison, the numbers are remarkably close from 1956 through about 1974. From 1975 through 1986, the advantage is Keynes's. From 1987 through 2006, the advantage is Schumpeter's-dramatically so from 1994 onwards. ${ }^{6}$

In Figure 2, we compare the major works of each author. The General Theory dominates from 1956 through 1990, dramatically so from the mid-1970s through the mid-1980s. Capitalism, Socialism and Democracy dominates from 1994 onwards, with the gap generally growing.

Figure 3 shows the proportion of Schumpeter's citations that are citations of Capitalism, Socialism and Democracy. A couple of generalizations are suggested by the graph. The proportion seems generally to fall from 1956 through 1964, and generally to increase from 1970 onwards. Since we associate creative destruction mainly with Capitalism, Socialism and Democracy, the increasing proportion of

\footnotetext{
${ }^{6}$ The citation evidence is broadly consistent with some expert observation, e.g.: "The 1980s and 1990s witnessed a dramatic increase in research that looked at Schumpeter's works and ideas for inspiration." (Becker and Knudsen 2005, p. 111)
} 


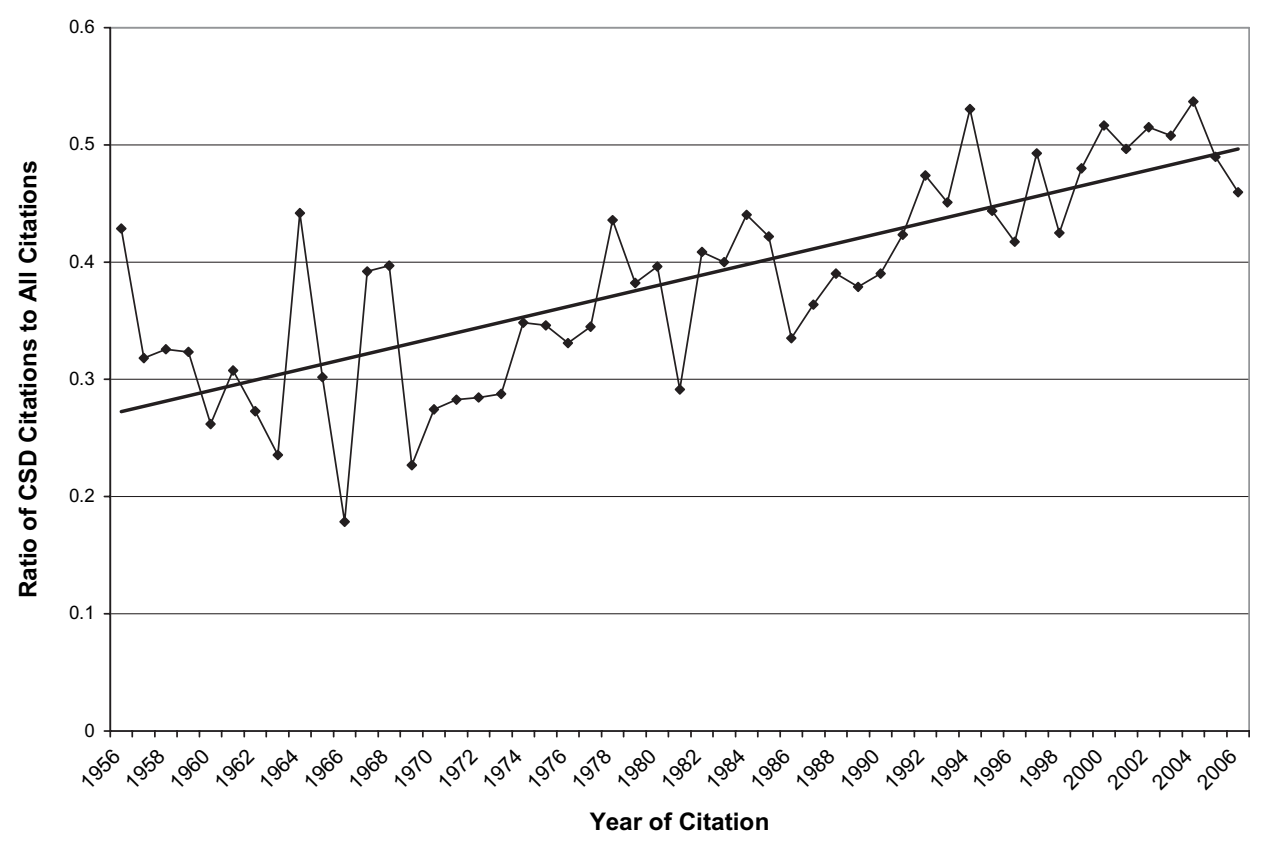

Figure 3. Proportion of All of Schumpeter's Citations that Are Citations to Capitalism, Socialism and Democracy

citations to that book might be interpreted as consistent with our claim that creative destruction is increasingly viewed as Schumpeter's central message.

\section{ECONOMICS CITATIONS TO SCHUMPETER (AND KEYNES) FROM 1956 TO 2006}

The Social Sciences Citation Index covers all of the social sciences, not just economics. So the results reported in the previous section do not allow us to conclude that Schumpeter's citations have increased within economics. Even though Schumpeter was primarily an economist, his methods and topics were broad enough to be of interest to other social scientists beyond economics.

So in order to learn if economists reflected the general pattern, we replicated Figures 1, 2, and 3, only this time counting only citations in economics journals. We counted as an "economics" journal any journal listed as an economics journal by the Institute for Scientific Information, any journal with any version of the word "economics" in the title, and academic journals in the finance subdiscipline. ${ }^{7}$ The results appear in Figures 4, 5, and 6.

\footnotetext{
${ }^{7}$ The journals counted as "economics" journals by the Institute for Scientific Information can be found at http://www.thomsonisi.com/cgi-bin/jrnlst/jlsubcatg.cgi?PC=J. In addition to the journals that met the criteria stated in the body of the paper, I also counted the following journals as "economics" journals: Cashiers Vilfredo Pareto and Zeitschrift Für Nationalökonomie.
} 


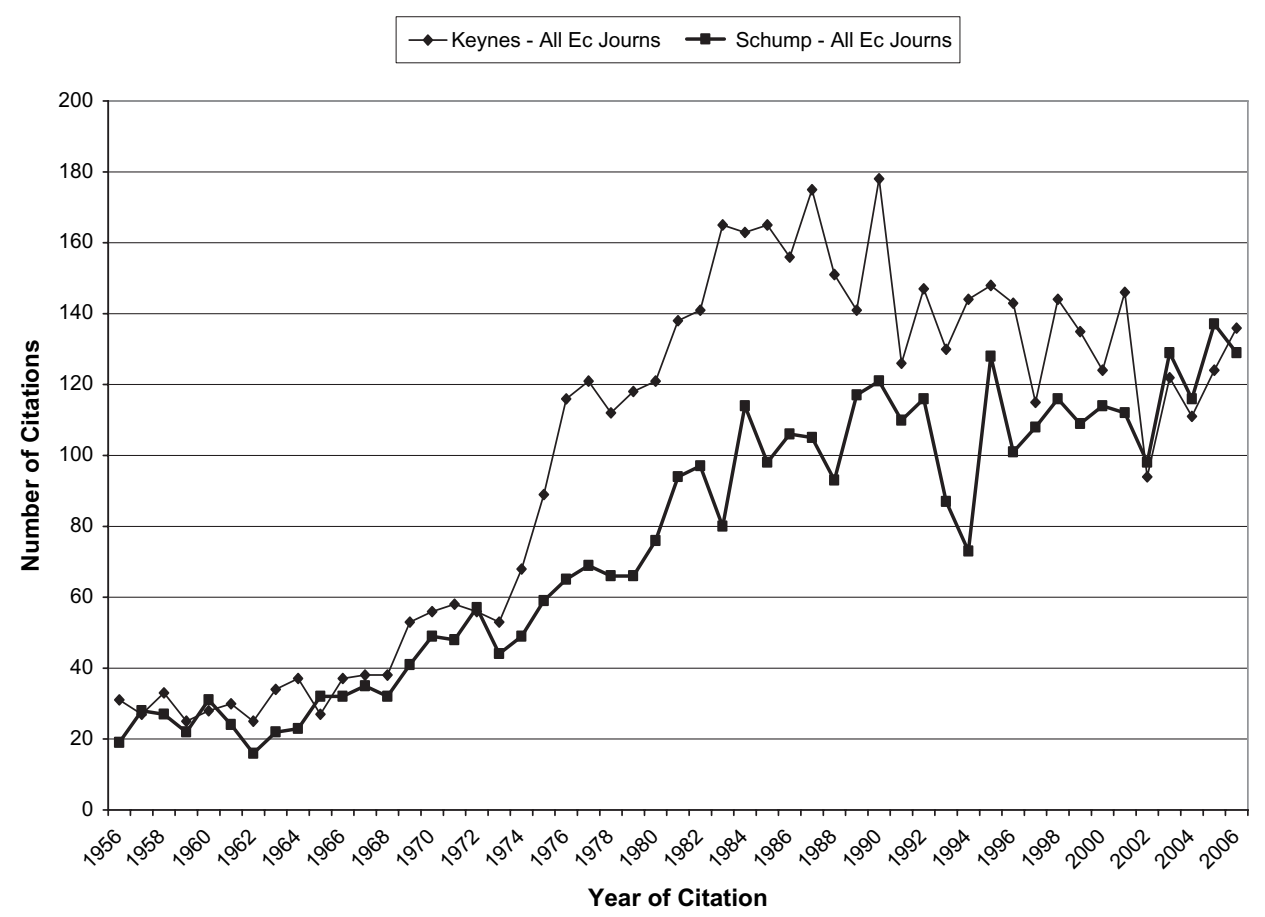

Figure 4. Schumpeter Versus Keynes: Total Citations Per Year to All Publications (Counting Citations Only from Economics Journals)

The main finding of the earlier section also applies robustly for economists as well: Schumpeter and Capitalism, Socialism and Democracy generally have been trending upwards throughout the range of observations; and Keynes and the General Theory generally have been trending modestly downward since roughly the mid-1980s.

Although the trends are similar, the magnitudes are different. So that while Schumpeter has clearly surpassed Keynes since the mid-1990s in the general data, he has only just caught up with Keynes since the mid-1990s in the data for economics journals. ${ }^{8}$

\section{CONCLUSIONS}

Creative destruction is being recognized as true and important by a growing number of social scientists and economists. I highlighted a few important, specific examples

\footnotetext{
${ }^{8}$ Our results are broadly consistent with those reported in Becker and Knudsen (2005, pp. 2-4). Using the online resource JSTOR, they examine occurrences of the name "Schumpeter" anywhere in the articles in the top-five economics journals, the top three sociology journals, and the top-five organization theory journals. Their data are narrow in scope, but broad in time, covering the century from 1898 to 1998. During that time, they find for the five economics journals that references to Schumpeter peaked in the mid 1950s, fell until 1978, and then entered a plateau in the 1980s and 1990s of roughly 50 references a year. The total number of references in the data dramatically increased, however, in the final 1988-1998 decade, due to a substantial increase in references in the organization theory journals.
} 


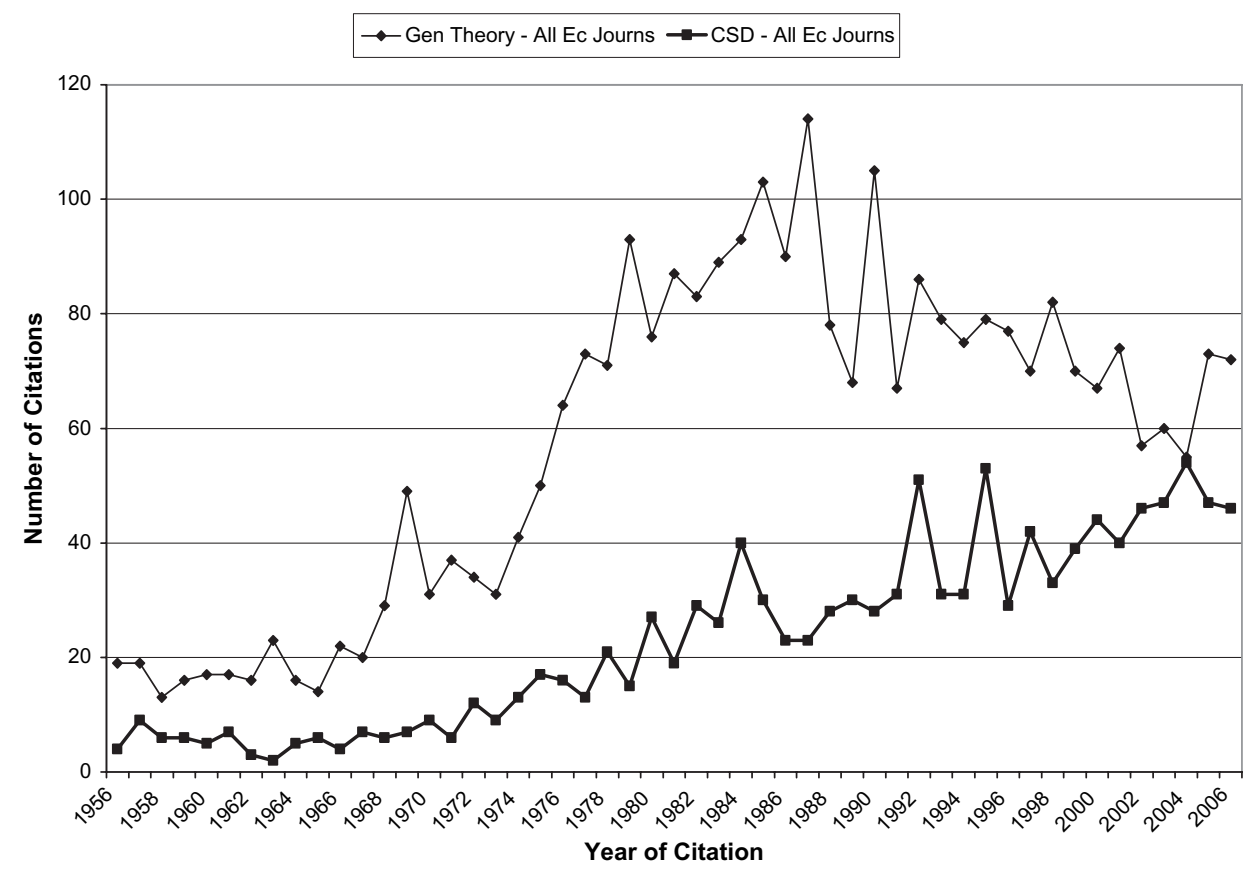

Figure 5. Schumpeter Versus Keynes: Citations Per Year to Capitalism, Socialism and Democracy Versus Citations Per Year to The General Theory (Counting Citations Only from Economics Journals)

of economists who have argued for the importance of the process. Beyond the examples, I present citation evidence of the broader-and increasing-influence of Schumpeter among both social scientists in general, and economists in particular. For social scientists and economists, I show that annual citations to Schumpeter have continued to increase more than 50 years after his death. For social scientists, since the mid-1990s, annual citations to Capitalism, Socialism and Democracy have even exceeded annual citations to Keynes's General Theory.

In the future, the current paper will be incorporated as part of a book entitled Openness to Creative Destruction. In the book, I will argue and present evidence that Schumpeter was right that creative destruction is the essential fact about capitalism. ${ }^{9}$ I will argue that new products and processes have the potential to make life substantially longer and better, and therefore there is a lot at stake in speeding up the pace of successful innovation. I will argue further that, although a growing number of prominent economists and business practitioners ${ }^{10}$ acknowledge the importance of creative destruction, economists should do better at incorporating creative destruction into what we teach, ${ }^{11}$ and what policy advice we give in areas such as antitrust, labor,

\footnotetext{
${ }^{9}$ Also see: Diamond 2006.

${ }^{10}$ Also see Diamond 2007b.

${ }^{11}$ Also see Diamond 2007a.
} 


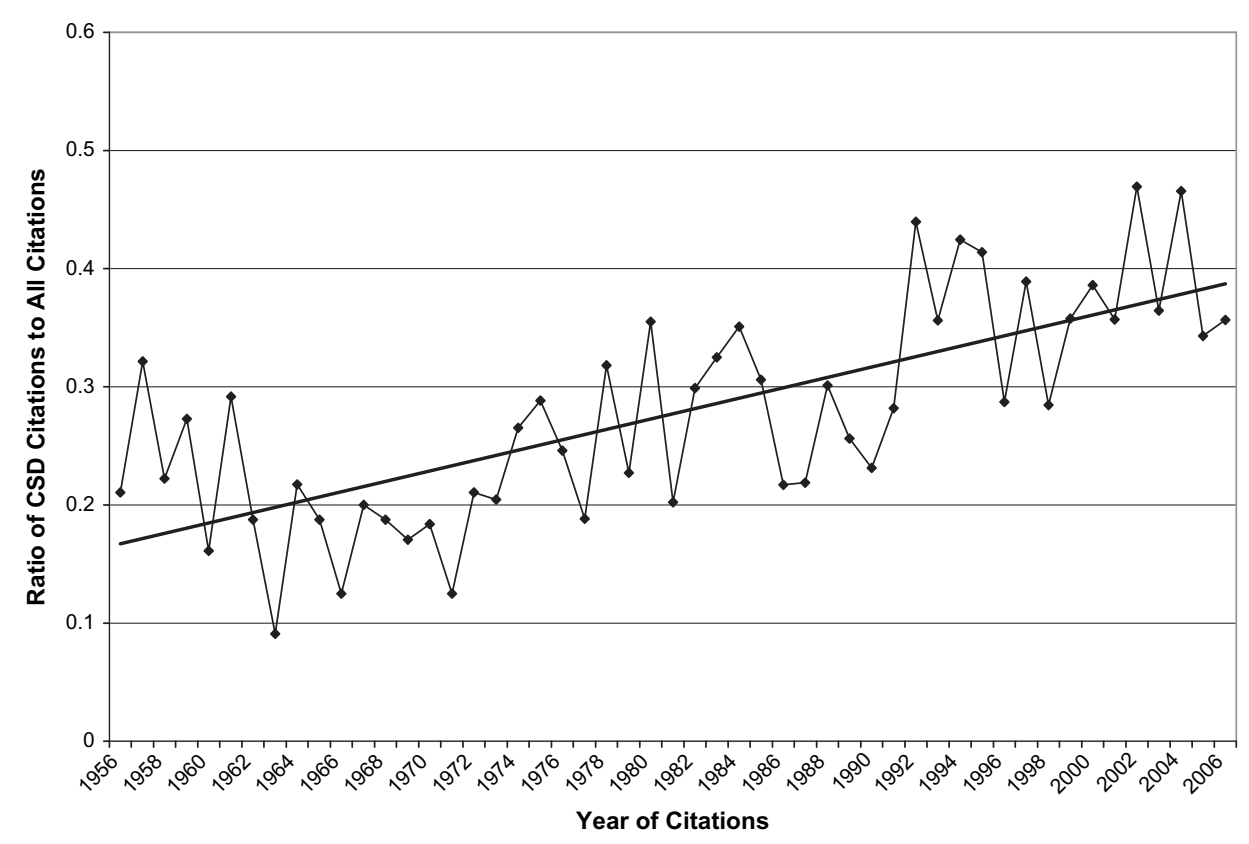

Figure 6. Proportion of All of Schumpeter's Citations that Are Citations to Capitalism, Socialism and Democracy (Counting Citations Only from Economics Journals)

and development. If we do a better job, the pace of innovation can accelerate, making the world a better place.

\section{ACKNOWLEDGMENTS}

I am grateful for excellent research assistance on this project from Angela Kuhlmann and Miaomiao Yu. I also received assistance from Brent Erickson and Molly McGrath. I thank Jeanette Medewitz for help in producing the graphs. A couple of lines of one of the footnotes, and most of the Appendix on Citation Issues, have been adapted from Diamond (2004, 2005). An earlier version of the current paper was presented at the biennial meetings of the International Schumpeter Society in Sophia-Antipolis, France in June 2006. I appreciate the suggestions of Markus Becker.

\section{REFERENCES}

Baily, Martin Neil. 2001. "Macroeconomic Implications of the New Economy." Proceedings, Federal Reserve Bank of the Kansas City, 201-68. [First presented at the Jackson Hole Conference of the Kansas City Federal Reserve Bank, August 2001.]

Baumol, William J. 2001. "Innovation and Creative Destruction.” In McKnight, Lee W., Paul M. Vaaler, and Raul L. Katz, eds. Creative Destruction: Business Survival Strategies in the Global Internet Economy. Cambridge, MA: MIT Press, pp. 21-38.

Baumol, William J. 2002. The Free Market Innovation Machine: Analyzing the Growth Miracle of Capitalism. Princeton: Princeton University Press. 
Becker, Markus C., Hans Ulrich Esslinger, Ulrich Hedtke, and Thorbjørn Knudsen. 2005. "Development by Joseph A. Schumpeter: Introduction.” Journal of Economic Literature 43 (1) (March): 108-111.

Becker, Markus C. and Thorbjørn Knudsen. 2005. "The Role of Entrepreneurship in Economic and Technological Development: The Contribution of Schumpeter to Understanding Entrepreneurship." Centre for Research on Entrepreneurship and Entrepreneurs Working Paper Series.

DeLong, J. Bradford and Lawrence H. Summers. 2001. “The 'New Economy': Background, Questions and Speculations." Federal Reserve Bank of Kansas City Economic Review (Fourth Quarter): 29-59. [Originally presented at the Jackson Hole Conference of the Kansas City Federal Reserve Bank, August 2001.]

Diamond, Arthur M., Jr. 1986. "What is a Citation Worth?” The Journal of Human Resources 21(2): 200-215.

Diamond, Arthur M., Jr. 2004. "Zvi Griliches's Contributions to the Economics of Technology and Growth.” Economics of Innovation and New Technology 13 (4) (June): 365-397.

Diamond, Arthur M., Jr. 2005. "Measurement, Incentives, and Constraints in Stigler's Economics of Science." The European Journal of the History of Economic Thought 12 (4) (Winter): 635-661.

Diamond, Arthur M., Jr. 2006. "Schumpeter's Creative Destruction: A Review of the Evidence." Journal of Private Enterprise 22 (1) (Fall): 149-161.

Diamond, Arthur M., Jr. 2007a. “The Neglect of Creative Destruction in Micro-principles Texts.” History of Economic Ideas 15(1): 197-210.

Diamond, Arthur M., Jr. 2007b. "Thriving at Amazon: How Schumpeter Lives in Books Today." Econ Journal Watch 4 (3) (September): 338-444.

Dogan, Mattei and Robert Pahre. 1990. "Scholarly Reputation and Obsolescence in the Social Sciences: Innovation as a Team Sport.” International Social Science Journal 42 (3) (August): 417-427.

Drucker, Peter F. 1999. "Modern Prophets: Schumpeter or Keynes?" Reprinted in The Frontiers of Management. New York: Penguin Putnam, Inc., Chapter 12, pp. 104-115 [originally published as: "Schumpeter and Keynes."Forbes (May 23, 1983): 124-128].

Feldstein, Martin. 2003. "Why is Productivity Growing Faster?" Presented at January AEA meetings in Washington D.C.

Garfield, Eugene. Various. Social Sciences Citation Index. Philadelphia, PA: Institute for Scientific Information.

Granstrand, Ove. 1994. "Economics of Technology-An Introduction and Overview of a Developing Field." In Ove Granstrand, ed., Economics of Technology. Amsterdam: North-Holland, pp. 1-36.

Griliches, Zvi. 2000. R\&D, Education and Productivity: A Retrospective. Cambridge, MA: Harvard University Press.

Hall, Bronwyn, Adam Jaffe, and Manuel Trajtenberg. 2000. "Market Value and Patent Citations: A First Look," NBER Working Paper 774. [Also: University of California Dept. of Economics Working paper E01-304 (August). A briefer version was published, but doesn't contain the material cited here.]

Helburn, Suzanne W. and David F. Bramhall. 1986. Marx, Schumpeter, and Keynes: A Centenary Celebration of Dissent. Armonk, NY: M.E. Sharpe.

Keynes, John Maynard. 1964. The General Theory of Employment, Interest, and Money. New York: Harcourt, Brace \& World (first published in 1936).

Mansfield, Edwin. 1995. Innovation, Technology and the Economy: The Selected Essays of Edwin Mansfield, Vols. I and II. Brookfield, VT: Edward Elgar.

Mokyr, Joel. 2002. "Review of William J. Baumol The Free-Market Innovation Machine: Analyzing the Growth Miracle of Capitalism". Economic History Services, (July 26), URL: http://www.eh.net/ bookreviews/library/0517.shtml

Moss, Laurence S. 1996. "Introduction.” In Moss, ed. Joseph A. Schumpeter, Historian of Economics. London: Routledge.

Rosenberg, Nathan. 1982. Inside the Black Box: Technology and Economics. Cambridge: Cambridge University Press. 
Samuelson, Paul A. 1981. "Schumpeter as an Economic Theorist." In Helmut Frisch, ed., Schumpeterian Economics. New York: Praeger, pp. 1-27.

Samuelson, Paul A. 2003. "Reflections on the Schumpeter I Knew." Journal of Evolutionary Economics 13 (5) (December): 463-467.

Schumpeter, Joseph A. 1950. Capitalism, Socialism and Democracy, 3rd edition. New York: Harper-Collins. Schumpeter, Joseph A. 1954. History of Economic Analysis. New York: Oxford University Press.

Stigler, George J. 1957. "Perfect Competition, Historically Contemplated." Journal of Political Economy, 65(1): 1-17 [Reprinted in Stigler, G. J. (1965c). Essays in the History of Economics. Chicago: The University of Chicago Press, pp. 234-267; also reprinted in Luebe, K. R. and T. G. Moore, eds. (1986). The Essence of Stigler. Stanford, CA: Hoover Institution Press, pp. 265-288].

Stigler, George J. 1976. "The Xistence of X-efficiency." American Economic Review 66 (1976): 213-216.

Stigler, George J. 1988. Memoirs of an Unregulated Economist. New York: Basic Books.

Wagener, H.-J. and J. W. Drukker. 1986. The Economic Law of Motion of Modern Society: A MarxKeynes-Schumpeter Centennial. Cambridge, UK: Cambridge University Press.

\section{APPENDIX: CITATION ISSUES}

Our source for citations is primarily the Social Sciences Citation Index portion of the Web of Science database published by the Institute for Scientific Information (ISI), incorporating citations in the sciences, social sciences, arts, and humanities. For the present research, the primary advantage of the Web of Science version of the database is that it has been extended back through 1956 for the social sciences, in contrast to the 1966 starting date for the Social Sciences Citation Index, which is the book version. Citation counts were available through the year 2006.

For Schumpeter, I used the search term "Schumpeter, $\mathrm{J}^{*}$ " in order to capture both citations using only his first name, and citations using both his first and middle initials. (The asterisk stands for "wildcard" which is necessary because citers, and ISI data-entry persons, sometimes record the same author or publication in differing forms.) For Capitalism, Socialism and Democracy, I used the search term "Cap* Soc*" which I judged would capture almost all, but not all of the citations to the book. (This method would miss, for example, citations to the German translation of the book, where the title begins with the letter " $K$ ".)

The search term for Keynes used was "Keynes, J*". For each year, I looked for and excluded the small number of citations to J. M. Keynes' father: John Neville Keynes. For the General Theory, I searched under the search terms "Gen* The*".

Although it is well known that citations are highly correlated with other measures of intellectual distinction and productivity (e.g., Diamond 1986), it is also well known that they are not a perfect measure.

Another potential imperfection in the citation data results from what is sometimes described as citation inflation: that the secular trend has been for the average citations per article to rise. But it is difficult to distinguish whether a general secular increase in citations represents a decline in the average value of a citation, or an increase in the average quality of an article. In this paper we concur with Hall et al. (2000, p. 36) who suggest that taking out time effects "... would drastically reduce the variance in the data, probably throwing out a good part of the baby with the bathwater." 